\title{
ОСОБЛИВОСТІ РОЗВИТКУ МУЗИЧНО-ПЕДАГОГІЧНОЇ ОСВІТИ В КНР
}

\author{
Чень Хуейхуей \\ здобувач третього (освітньо-наукового) рівня вищої освіти кафедри \\ освітології та інноваційної педагогіки, Харківський національний \\ педагогічний університет імені Г. С. Сковороди, м. Харків, Україна

\section{Цзен Гуанхай} \\ здобувач третього (освітньо-наукового) рівня вищої освіти кафедри \\ освітології та інноваційної педагогіки, Харківський національний \\ педагогічний університет імені Г. С. Сковороди, м. Харків, Україна
}

У статті схарактеризовано становлення витоків музичної освіти в Китаї та визначено особливості ї̈ розвитку. Розглянуто процес реформування системи музично-педагогічної освіти та ї̈ сучасний стан в Китаї. Зазначено, щчо становлення музично-педагогічної освіти в Китаї відбувалося иляхом імплементації різним форм, методів та засобів у процес підготовки майбутніх учителів музики з різних краӥн.

Ключові слова: музична освіта, музично-педагогічний процес, особливості, Китай.

The article characterizes the formation of the origins of music education in China and identifies the features of its development. The process of reforming the system of music and pedagogical education and its current state in China is considered. It is noted that the formation of music and pedagogical education in China took place through the implementation of various forms, methods and tools in the process of training future music teachers from different countries.

Key words: music education, music-pedagogical process, features, China.

Історія становлення професійної музично-педагогічної освіти у Китаї налічує близько 100 років. На різних етапах еволюції китайської музичної освіти, розпочинаючи з 1920-х років, створювалися спеціальні навчальні музичні заклади, насамперед Шанхайська державна консерваторія та Центральна державна консерваторія у Пекіні. Центральна консерваторія - найбільший музичний університет у Китаї. За роки свого існування в ній склалася система неперервної музичної освіти, в якій поєднуються всі щаблі, починаючи від дитячої музичної школи, музичного училища до консерваторії, аспірантури та докторантури. 
До складу консерваторії входять 8 факультетів: музикознавчий, композиторський, диригентський, вокально-оперний, фортепіанний, оркестровий, факультети музичної освіти та традиційних китайських інструментів.

Викладаються понад 200 дисциплін за фахом. Консерваторія користується великим авторитетом у становленні музичної освіти у Китаї та за кордоном.

У консерваторії звертають особливу увагу на вдосконалення професійного рівня викладачів, запрошують іноземних музикантів-педагогів для навчання грі на музичних інструментах та читання теорії музики, складають посібники відповідно до вимог традиційної музичної освіти [1, с. 209-210].

Після утворення КНР (1949) культурна політика держави була спрямована на посилення ролі літератури та мистецтва серед широких верств населення. У Пекіні були організовані Всекитайська асоціація літератури та мистецтва та Спілка працівників музики (з 1959 р. Союз китайських музикантів).

У 80-ті роки у китайських університетах була прийнято міжнародну систему ступенів: бакалаврат-магістратура-докторантура. Кожен Університет має свої правила вступу.

Для того, щоб бути прийнятим на бакалаврську програму до державного 3ВО, необхідно бути не старшим 25 років і мати атестат про середню освіту.

У 1980 р. Міністерством освіти країни було видано «Навчальний план підготовки фахівців у галузі музики для педагогічних $3 \mathrm{BO}$ із чотирирічним терміном навчання», а 1982 р. вийшли аналогічні документи для ЗВО з дво- та трирічним термінами навчання. У цих трьох документах були визначені: цілі навчальної та практичної підготовки фахівців; навчальні дисципліни — обов'язкові та факультативні; завдання та напрями наукових досліджень; встановлено терміни навчання; порядок прийому до ЗВО тощо [3, с. 38-39].

Дуже важливим заходом підвищення якості підготовки фахівців стала розробка програми вступних випробувань.

У 1987 р. професія «вчитель музики» увійшла до каталогу спеціальностей, підготовка за якими велася в педагогічному університеті.

Таким чином, була конкретизована мета музичної освіти у педагогічних університетах — підготовка фахівців для роботи у загально- 
освітніх школах. На цьому етапі рішення стосувалося підготовки вчителів для базової школи (7-9 класи).

Після 1983 р. Міністерство освіти відповідно до існуючого плану доручає викладачам музичних факультетів педагогічних ЗВО складати підручники за різними дисциплінами (рояль, акордеон, вокальна майстерність, спів з аркуша, хор, методика тощо), що дало змогу забезпечити навчальною літературою ЗВО. В деяких ЗВО з власної ініціативи розроблялися спеціальні додаткові посібники. У перших підручниках 3 методики викладання музики в школі отримало відображення прагнення до систематизації матеріалу та наукового обгрунтування питань педагогічної теорії, утім ще мало уваги приділяється розробкам, пов'язаним зі специфікою навчання дітей музичним дисциплінам [4, с. 51].

Якість навчально-методичної літератури значно підвищилася у 1990-ті роки. Успішно поєднуючи завдання теорії та практики, орієнтовані на розвиток практичних навичок, вони стали повноцінними навчальними посібниками для 3ВО, що використовуються на багатьох музичних факультетах і нині.

Важливою сферою діяльності держави у цей період стало забезпечення шкіл дипломованими фахівцями. Упродовж тривалого часу у школах не вистачало викладачів музики. У зв'язку з цим з початку десятиліття у XXI ст. усі музичні факультети педагогічних ЗВО розпочали розширювати масштаби прийому студентів, організовувати навчання за скороченими програмами [2, с. 126-129].

Створювалися факультети з дво- та трирічним терміном навчання, підвищення кваліфікації вчителів музики початкових та середніх шкіл. У деяких педагогічних ВНЗ відкривалися групи для дорослих, а на заочних та вечірніх відділеннях університетів організувалися іспити для тих, хто займався музичною самоосвітою. У 1987 р. Педагогічному інституті китайського телебачення відкрилися спеціальні курси. Здобувачі, які закінчили програму навчання з професійної освіти, складали іспити та отримували сертифікат чи атестат. До середини 1990-х рр. у педагогічних та спеціальних ЗВО країни було підготовлено таку кількість шкільних вчителів музики, що дозволило значно пом'якшити гостроту проблеми підготовки педагогів-музикантів.

Таким чином можна визначити особливі риси музичної освіти у Китаї. 
Національні особливості кожного народу відбиваються у культурі. Китай - багатонаціональна країна із найдавнішою культурою. Китайська культура характеризується культурною єдністю, своєрідністю та унікальністю, зокрема й музичної. Концепцію естетичного та музичного виховання визначають музичні ідеї стародавнього філософа Конфуція, естетичні ідеї нового культурного руху Кан Ювей, Лян Цічяо, які орієнтовані на вдосконалення особистості, наснагу, збагачення душі; самовдосконалення, виховання чесноти, нормативної поведінки. Сучасні концепції музичної освіти Китаю також орієнтуються на цю змістову лінію, виховують особистість з активним ставленням до життя, здатного сприймати та любити красу оточуючого світу.

Слід також зазначити, що становлення системи музичної освіти у Китаї здійснюються під впливом зарубіжних методик музичної освіти, формуючи власну унікальну систему.

\section{Список використаних джерел:}

1. Жерновникова О. А., Ван Цзін І. Формування та становлення особистості майбутнього педагога засобами музичного мистецтва. Педагогічний альманах : зб. наук. праць. Херсон : КВНЗ «Херсонська академія неперервної освіти», 2017. Вип. 36. С. 208-212.

2. Доброскок I. І., Наливайко О.О., Рибалко Л.С., Жерновникова О.А. Впровадження цифрових ресурсів у процес підготовки музикантів-педагогів у навчальних закладах КНР. Професійна освіта: методологія, теорія та технології. Переяслав-Хмельницький : СКД, 2020. Вип. 12. С. 123-137.

3. 孙晓婕. 俄罗斯音乐教师的教育培养体系.中国音乐教育,2008(01):37-41 [Сун Сяоцзе. Система освіти та підготовки вчителів музики. Музична освіта в Китаї. 2008 (01): 37-41].

4. 王文瑜. 高等音乐院校师资队伍现状与发展.科教导刊(上旬刊),2015(04):51-52 [Ван Венью. Сучасна ситуація та розвиток факультету вищих музичних коледжів. Journal of Science Education, 2015 (04): 51-52]. 